\title{
The population dynamics and feeding preferences of Bursatella leachii (Opisthobranchia: Anaspidea) in northeast Queensland, Australia
}

\author{
Cathryn L. Clarke \\ James Cook University, Townsville, Queensland 4811, Australia \\ Email: ClarkeCa@pac.dfo-mpo.gc.ca
}

\begin{abstract}
Sea hares (Opisthobranchia: Anaspidea) have long been known to form dense aggregations in shallow marine habitats. However, there have been few attempts to document the dynamics and causes of these aggregations. The present report investigates the population dynamics of Bursatella leachii found in association with a cyanobacterial bloom in tropical north Queensland, Australia. The aggregation was fuelled by a continual source of recruits and in laboratory testing, this population preferred a green alga to its prey item in the field, the cyanobacterium, Calothrix crustacea. Therefore, $B$. leachii has the ability to continually recruit in large numbers to seagrass beds in order to exploit an abundant but less preferred food resource.
\end{abstract}

Key words: Bursatella leachii, Stylocheilus striatus, sea hare, Anaspidea, feeding preference

\section{INTRODUCTION}

The single unifying feature of all populations is their dynamism. Documenting natural population fluctuation has become increasingly important in recent times where the need exists to distinguish natural fluctuations in systems from those caused by anthropogenic disturbance. The majority of fluctuations in populations occur on a local scale (Smith 1996). Aggregations of large numbers of animals in a single area are an extreme example of population fluctuation. These events are referred to as population explosions or irruptions (Colgan 1987; Burla and Ribi 1998; Cote and Reynolds 1998; Williams et al. 2001). These aggregations are often an obvious and highly visible incident to human visitors to the site in question and can have a strong effect on the local animal and macrophyte communities.

A range of largely anecdotal evidence suggests that some sea hare species exhibit boom-and-bust cycles, forming large aggregations and then disappearing. There are a number of hypotheses as to why populations of sea hares exhibit this dynamic. One hypothesis for the cause of aggregation is a response to hydrological conditions. Lowe and Turner (1976) hypothesized that aggregations of juvenile Bursatella leachii were caused by the hydrological conditions in subtidal habitats. In addition, the intensity of water movement in Israel intertidal habitats was negatively related to adult sea hare abundance (Plaut et al. 1998). The occurrence of sea hares in intertidal habitats may be a compromise between a preference for low-intensity wave action and their preference for intertidal algae species. In one year, Plaut et al. (1998) observed a rare algal bloom in deeper water and Aplysia oculifera was found in greater abundance in association with this bloom than those populations in the exposed shallowwater habitats.

The second hypothesis is that the sea hares settle in a range of habitats and migrate to areas of highly dense conspecifics for the purpose of breeding. In California surf-grass beds, Aplysia californica form dense breeding aggregations in summer months (Audeskirk 1979). Breeding aggregations of $B$. leachii during the Florida winter were also observed but animals in summer aggregations were mostly immature (Lowe and Turner 1976).

The third hypothesis for aggregation is that it occurs where food is localized (Carefoot 1987). In habitats where food is concentrated sea hares may aggregate incidentally as a result of larval settlement or feeding preferences. That is, a large recruitment of sea hares may settle in an area where a preferred host alga is high in abundance. In Israel, $A$. oculifera abundance was highly correlated with the variable presence of species of Ulva and Enteromorpha (Plaut et al. 1998). A. californica juveniles for example, are primarily found on the red algae Plocamium cartilagineum and Laurencia pacifica (Pennings 1991). However, Pawlik (1989) demonstrated that $A$. californica settles on a wide range of algae and crawls to the preferred species. Sites with greater $P$. cartilageum cover contained higher numbers of $A$. californica recruits however 
this characteristic did not explain the variation in recruitment intensity which may be related to larval supply (Pennings 1991). The combination of favourable larval conditions and a high abundance of a preferred algae species for competent larvae may cause high settlement of juveniles in these areas.

The key to this last hypothesis is the feeding preference of the sea hare species under investigation. On the whole, feeding specialists seem to be relatively rare in the marine environment when compared with terrestrial systems (Lubchenco and Gaines 1981; Hay et al. 1989). In contrast, most sea hares are relatively specialized feeders and there is a substantial body of work addressing the feeding preferences of various species (Carefoot 1967, 1987; Wu 1980; Pennings 1990b; Pennings et al. 1993; Rogers et al. 1995; Nagle et al. 1998). These studies had mixed results and it can be difficult to sort out the factors influencing feeding preference in sea hares. Factors such as nutritional value, abundance, secondary chemistry and biotic interactions have previously been the focus of sea hare feeding preference studies. Analyses of the nutritional qualities of algae tested for sea hare feeding preferences have largely failed to correlate specific qualities with feeding preferences (e.g., Carefoot 1967, 1970; Rogers et al. 1995).

Foraging theory states that feeding on the most abundant and therefore readily obtainable food sources will require the least energy and thus is most advantageous to the herbivore (Crawley 1983). We would expect therefore that sea hares would prefer abundant algae. This is true for some species under certain conditions. For example, the specialist sea hare, Aplysia juliana, feeds on and occupies the abundant green alga, Ulva lactuca, both in the laboratory and in the field (Carefoot 1970; Rogers et al. 1995). In contrast, Aplysia parvula utilizes two species of algae which are rare in the local environment (Rogers et al. 1995).

Numerous studies have examined the influence of algal secondary chemistry on the feeding preferences of sea hares. Investigations into the role of these chemicals have produced mixed results. The generalist herbivore, Dolabella auricularia, was relatively unaffected by the presence of chemical defences in the host algae (Pennings and Paul 1992). Yet, other sea hare species seem to be substantially affected by the type and concentration of macrophyte secondary metabolites (Stylocheilus striatus: Nagle et al. 1998; A. parvula: Ginsburg and Paul 2001).

Physical characteristics of the host macrophyte have been mostly overlooked in general studies on sea hare feeding preferences. One exception is the study by Pennings and Paul (1992) where the authors demonstrated that low preference is negatively correlated with macrophyte toughness and calcification in $D$. auricularia. In addition, the feeding preferences of $A$. californica have been found to expand with ontogenetic development (Pennings $1990 \mathrm{~b}$ ) and this trend was thought to be caused by the soft, weak mouth parts found in younger individuals.

Biotic interactions, either competition or predation, have also rarely been examined as influences on feeding preferences in sea hares. Competition has been suggested by some authors (Willan 1979; Achituv and Susswein 1985) although never directly tested. Two studies on the influence of predation on feeding preferences yielded contradictory results (Pennings 1990a; Rogers et al. 2000, 2002).

Stylocheilus striatus and $B$. leachii are often reported to be found in dense feeding aggregations in association with blooms of cyanobacteria (Switzer-Dunlap and Hadfield 1979; Paul and Pennings 1991). The dynamics of these aggregations has never been quantitatively examined for either of these two species. A sole report, Lowe and Turner (1976) examined aggregations of B. leachii at a beach in Florida but measured the densities of animals washed up on the shoreline, therefore giving no indication of the natural density of this species. The temporal dynamics of these types of aggregations have not been previously investigated and therefore, the underlying cause of population irruption in sea hares is unknown. In addition, the feeding preferences of $B$. leachii have not been determined for tropical populations. This report tests the third hypothesis as the cause for the aggregations observed in tropical North Queensland; that is, aggregations caused by common feeding preferences. The population dynamics of this aggregation were examined using descriptive length-frequency analysis to test whether $B$. leachii settled in a single pulse of recruitment. Laboratory feeding preference was tested to shed light on whether these sea hares were aggregating in response to a preferred food item.

\section{MATERIALS AND METHODS}

\section{Population monitoring}

Sea hare population sampling was conducted at a site in Cleveland Bay near Townsville, Queensland, Australia $\left(19^{\circ} 10^{\prime} \mathrm{S}, 146^{\circ} 45^{\prime} \mathrm{E}\right)$. Cleveland Bay is a shallow embayment spanning $30 \mathrm{~km}$ protected from the prevailing winds by Magnetic Island, Cape Cleveland and the Great Barrier Reef (Lanyon and Marsh 1995). Cleveland Bay is slightly turbid as a result of freshwater runoff from local creeks, a shipping channel and re-suspended sediment from wave turbulence (Walker and O'Donnell 1981). The tidal pattern in these waters is mixed semi-diurnal. 
Cleveland Bay is tropical but experiences large seasonal variation in rainfall and minor temperature changes between summer and winter months (Lanyon and Marsh 1995).

The study site, Shelly Beach, is a shallow bay covered by seagrass beds dominated by three species, Halodule uninervis, Halophila ovalis, and Zostera capricornis. The site is located at the northern end of Rowes Bay and faces east towards Magnetic Island. Mangrove forest lies at the northern end and a rocky point at the south end. Shelly Beach is an ideal place to closely examine the population dynamics of $S$. striatus and B. leachii because of the relative simplicity of the benthic habitat. The Shelly Beach seagrass beds are never completely dry because some water is retained even at extremely low tides. Therefore sampling can be completed at low tide as sea hares are not forced to migrate by dropping water levels.

Five sampling trips were made to the Shelly Beach seagrass beds on 25 June, 7 July, 21 July, 27 July, and 3 September 2002. On each trip three $25 x$ $0.5 \mathrm{~m}$ belt transects were run parallel to the beach, yielding an estimate of sea hare density per $12.5 \mathrm{~m}^{2}$. Transects were run at approximately $100 \mathrm{~m}$ from the shore and were always oriented parallel to the beach to eliminate the effect of tidal height and to keep the measurement area within the dense seagrass habitat. Within each transect the sea hare species present and the number and length of individual sea hares was recorded. The sea hare species present was identified according to Coleman (2001). The length of each sea hare was measured by placing the individual on the transect tape and allowing the animal a few seconds to start to crawl along it. Once crawling, the distance between the base of the cephalic tentacles and the tip of the tail was recorded. The number of sea hare egg masses observed within transects was also recorded, although the species of egg mass could not be identified in the field.

During the five sampling trips, algae for laboratory feeding preference testing were collected. In total, three species of macroalgae (Enteromorpha ${ }^{1}$ sp., Sargassum sp., and Pterocladia pinnata) and one species of cyanobacterium (Calothrix crustacea) were tested. The latter species was the cyanobacterium found in the cyanobacterial bloom where the sea hares were collected and was an observed prey item of $B$. leachii in the field. Filamentous C. crustacea was collected directly from seagrass beds at Shelly Beach, growing epiphytically on seagrass blades or the benthos. The green alga, Enteromorpha sp., was chosen as a chemically poor species (Pennings et al. 1993) and was collected from the algal scrubbers at the JCU aquaculture facility. Sargassum sp. (Phaeophyta: Fucules) and $P$. pinnata (Rhodophyta) were chosen for their abundance in areas where $B$. leachii is found along the coast of Queensland, although they were not abundant at the site where the animals were collected. Red and brown algae were only present at extremely low densities in the study site so Sargassum sp. and P. pinnata were collected from Kissing Point, Rowes Bay, Townsville.

For feeding preference assays, 40 individual $B$. leachii were collected at low tide from the study site. Animals were placed in fresh seawater in $1 \mathrm{~L}$ containers and transported back to the laboratory located in the Marine Biology and Aquaculture Research Facility Unit (MARFU) aquarium system at James Cook University (JCU). All B. leachii were placed in a large aquarium (maintenance tank) supplied with continuously flowing filtered seawater (salinity $\sim 33 \mathrm{ppt}$, $\mathrm{pH} \sim 8.0$, temperature $27-28^{\circ} \mathrm{C}$ ). Animals were held overnight to allow acclimatisation before experimentation. Both maintenance and experimental tanks were on a 12h:12h light:dark diel cycle.

\section{Feeding assays}

Sixteen replicate $1.5 \mathrm{~L}$ aquaria supplied with continuously flowing filtered seawater acted as the experimental arenas. Pre-weighed, equal amounts (approximately $2 \mathrm{~g}$ wet weight) of each of two species of macroalgae or cyanobacteria were placed at opposite ends of each experimental arena. For each two-way choice experiment, eight experimental tanks and eight control (no-herbivore) replicates were used. Control tanks were identical in design and set-up, except for the absence of the herbivore. The loss of algae in the control tanks was used to calculate the loss of algae due to autogenic change from natural breakdown in the experimental tanks. Experimental tanks were randomly assigned at the start of each trial to remove the possibility of any single aquariaassociated bias. At the commencement of a trial, the wet weight of each alga in each tank was recorded and a randomly chosen $B$. leachii from the maintenance tank was placed at the centre of each experimental tank. Individual sea hares were allowed to move about the experimental tank and feed for a 24-hour period. Five times over the course of the trial, the position of each individual sea hare was recorded and scored as to presence on alga 1, alga 2, or on the tank walls (Attractiveness trial). At the termination of the trial, all algae was removed from the aquaria, patted dry and reweighed to determine percentage consumption of each alga (Palatability trial).

\footnotetext{
' The genus Enteromorpha has recently been merged with the genus Ulva (Hayden et al. 2003). Throughout the present work 'Enteromorpha' has been used to designate the filamentous growth form of the genus Ulva.
} 
Statistical analysis

Descriptive length-frequency analysis was used to examine the population dynamics of the sea hare population. Length-frequency analysis is a technique that examines changes in length of the population, using a series of length histograms. Length-frequency distribution reflects the interaction between rates of reproduction, growth, and mortality. Simple descriptive length-frequency analysis is used here to draw basic conclusions about the characteristics of the population. More formal length-frequency techniques could not be used because the full life history characteristics of these species have not been tested. The sea hare lengths were divided into $5 \mathrm{~mm}$ classes as this provided the best resolution of the patterns of recruitment and mortality. One-way ANOVA was performed on the length of sea hares found during each trip.

For the feeding preference trials, the autogenic change calculated for each alga was used to correct the percentage consumption values (after Nicotri 1980; Peterson and Renaud 1989). Paired-samples ttests were used to analyse the percentage consumption and behavioural choice data from each two-way choice trial. Where the data did not meet the assumptions of heterogeneity and normality a non-parametric Wilcoxon-signed ranks test was used to assess significance.

\section{RESULTS}

\section{Aggregation characteristics}

Sea hares were found in high abundance at Shelly Beach from 25 June to 27 July 2002. Two species of sea hare were present: $B$. leachii and S. striatus. Individuals of the two species were observed in the same areas, often in close association. A cyanobacterial bloom was also present at Shelly Beach during the sea hare population irruption. The cyanobacterium was identified as C. crustacea (B. Bendell, JCU, pers. comm.) and was present both in large tufts on the sediment and growing epiphytically on the seagrass leaves.

During the initial sampling trip, $25^{\text {th }}$ June 2002, only $B$. leachii was recorded in the transect area. The mean density of $B$. leachii at this time was 5.12 individuals per $\mathrm{m}^{2}$ (Figure 1). The highest recorded density of $B$. leachii was observed on 7 July when it increased to 7.44 individuals per $\mathrm{m}^{2}$ and then decreased in the subsequent sampling trips. No animals were recorded on the final sampling trip, 3 September 2002. Throughout the entire month of sampling, the predominant species remained $B$. leachii (Figure 1). The density of $S$. striatus was much lower than that recorded for $B$. leachii for the duration of the population irruption.

Stylocheilus striatus was first recorded within the

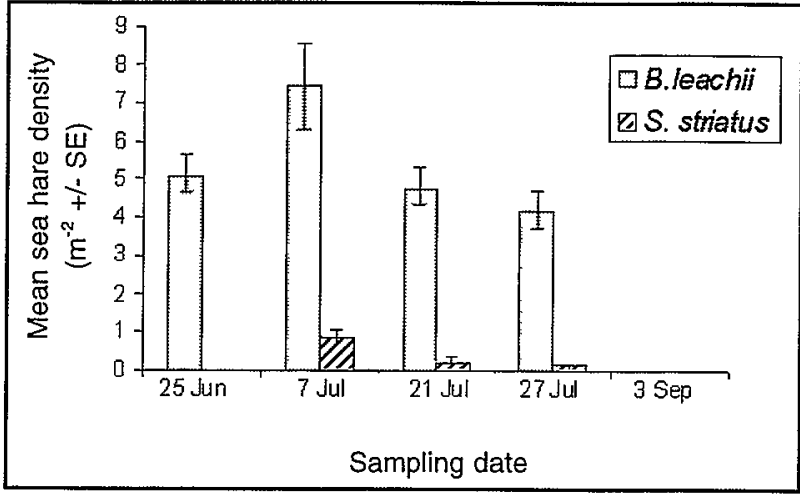

Figure 1 The mean density (per $\mathrm{m}^{2}$ ) of Bursatella leachii and Stylocheilus striatus within the seagrass beds of Shelly Beach in 2002.

transect area on $7^{\text {th }}$ July 2002 . Its density peaked at 0.88 individuals per $\mathrm{m}^{2}$ and steadily declined in the following trips until no animals were recorded on 3 September 2002. The mean density of $S$. striatus when present $\left(7^{\text {th }}, 21^{\text {st }}\right.$, and $27^{\text {th }}$ July, 2002) was 0.42 per $\mathrm{m}^{2}$ (Figure 1). Formal analysis of the length of $S$. striatus was performed but is not included here because it did not illuminate any useful trends for this study. This may be a result of the relatively low abundance recorded during most sampling trips.

\section{Pulse settlement vs. continuous recruitment}

Evidence against a pulse settlement event is the mean size of each sampling trip. The sizes of $B$. leachii found during each of the four sampling trips were significantly different (One-way ANOVA: df $=3, F=35.588, \mathrm{p}<0.001$ ). There was a decrease in mean length of $B$. leachii between 25 June and 7 July, a small increase during 21 July and then another small decline during 27 July (Figure 2). The animals found on 25 June and 21 July were significantly similar in size and those in 7 July and 27 July were significantly similar in size (Tukey's

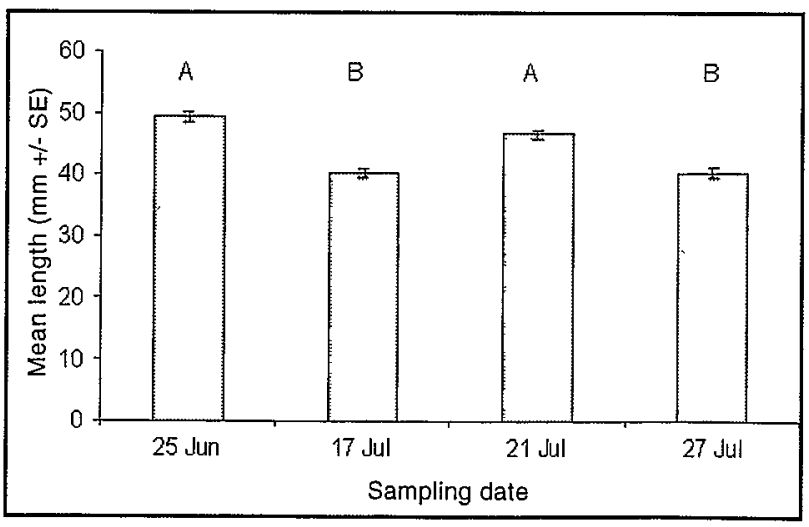

Figure 2 The mean length ( $\mathrm{mm}+/$ - standard error) of Bursatella leachii individuals during the four sampling trips to Shelly Beach in 2002. The letters denote significantly different subgroups as determined by Tukey's HSD posthoc tests. 

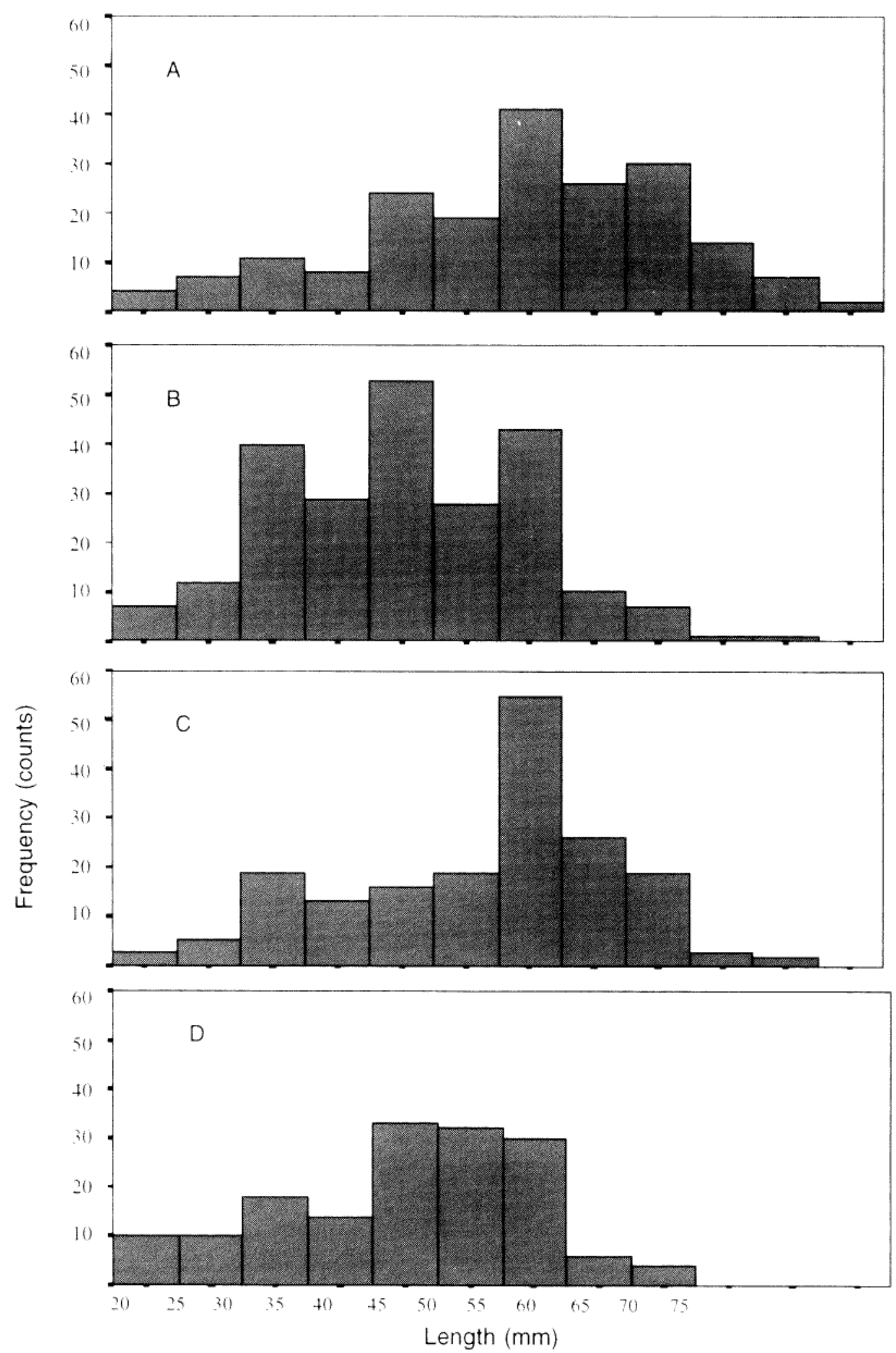

Figure 3 Length-frequency histograms of Bursatella leachi present at Shelly Beach in 2002 during each of the four sampling trips where af 27 lune, bi 7 July, c) 21 July, and d) 27 July:

HSD post-hoc tests: homogeneous subsets $A$ and $B$, Figure 2). This indicates that there was more than a single settlement event occurring at Shelly Beach.

There was continual recruitment of smaller individuals into the population at Shelly Beach during the sampling period (Figure 3). The small sea hares grew larger and moved into the larger sizt classes during the course of sampling in Figure 3. There was also a gradual decline in the abundance of larger size classes and the three largest classes disappeared completely in the last sampling trip of. In late June 2002, the size classes were normally distributed with a peak at the $50 \mathrm{~mm}$ length class although there were slightly more 
individuals in the larger size classes (Figure 3a). In early July, there was a peak of $40 \mathrm{~mm}$ animals and two smaller peaks at 30 and $50 \mathrm{~mm}$. There were a high proportion of smaller individuals at this time (Figure 3b). There was an increase in the number of larger individuals sampled during the 21 July sampling trip (Figure 3c). At the end of July no one size class dominated the distribution and again there was an increase in the number of small individuals (Figure 3d).

\section{Egg mass variation}

The presence of characteristic string-like sea hare egg masses within the sampling area indicated spawning activity and the presence of reproductively mature sea hares. However, which sea hare species had laid each mass could not be identified from the egg masses themselves in a field setting. The egg mass density during the 2002 sea hare population irruption peaked on July $7^{\text {th }}$ (Figure 4), which corresponds with the timing of the peak in sea hare density (see Figure 1). The density of egg masses at this time was 2.28 egg masses per $\mathrm{m}^{2}$.

\section{Palatability}

Bursatella leachii significantly preferred the green alga Enteromorpha over all other species tested,

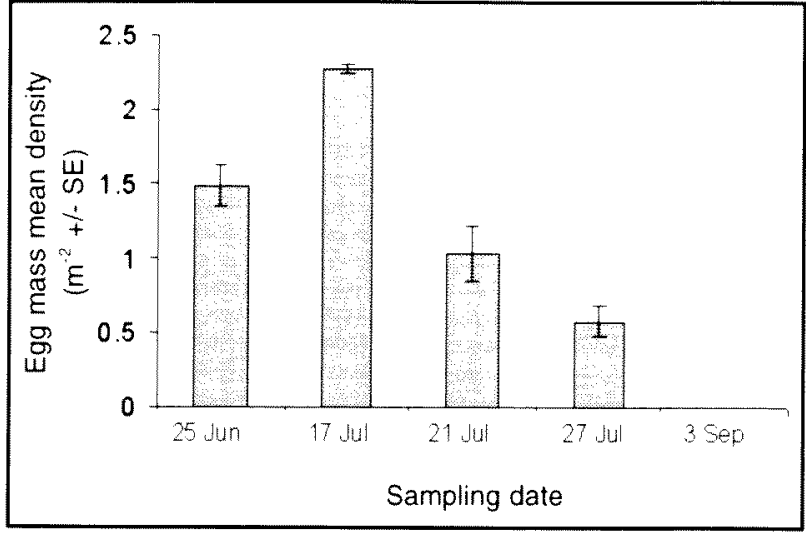

Figure 4 The mean density of egg masses (per $\mathrm{m}^{2},+1-$ standard error) found during each sampling trip within the seagrass beds of Shelly Beach in 2002.

including the cyanobacteria, $C$. crustacea. The mean percentage consumption, corrected for autogenic change, of each pair-wise trial is shown in Figure 5. Only Enteromorpha and C. crustacea were consumed in amounts greater than $10 \%$. The feeding preference hierarchy of $B$. leachii was Enteromorpha sp. > C. crustacea $>$ Sargassum sp. and P. pinnata. Enteromorpha was consumed significantly more than C. crustacea (Wilcoxon Signed ranks test: $Z=-2.240$,

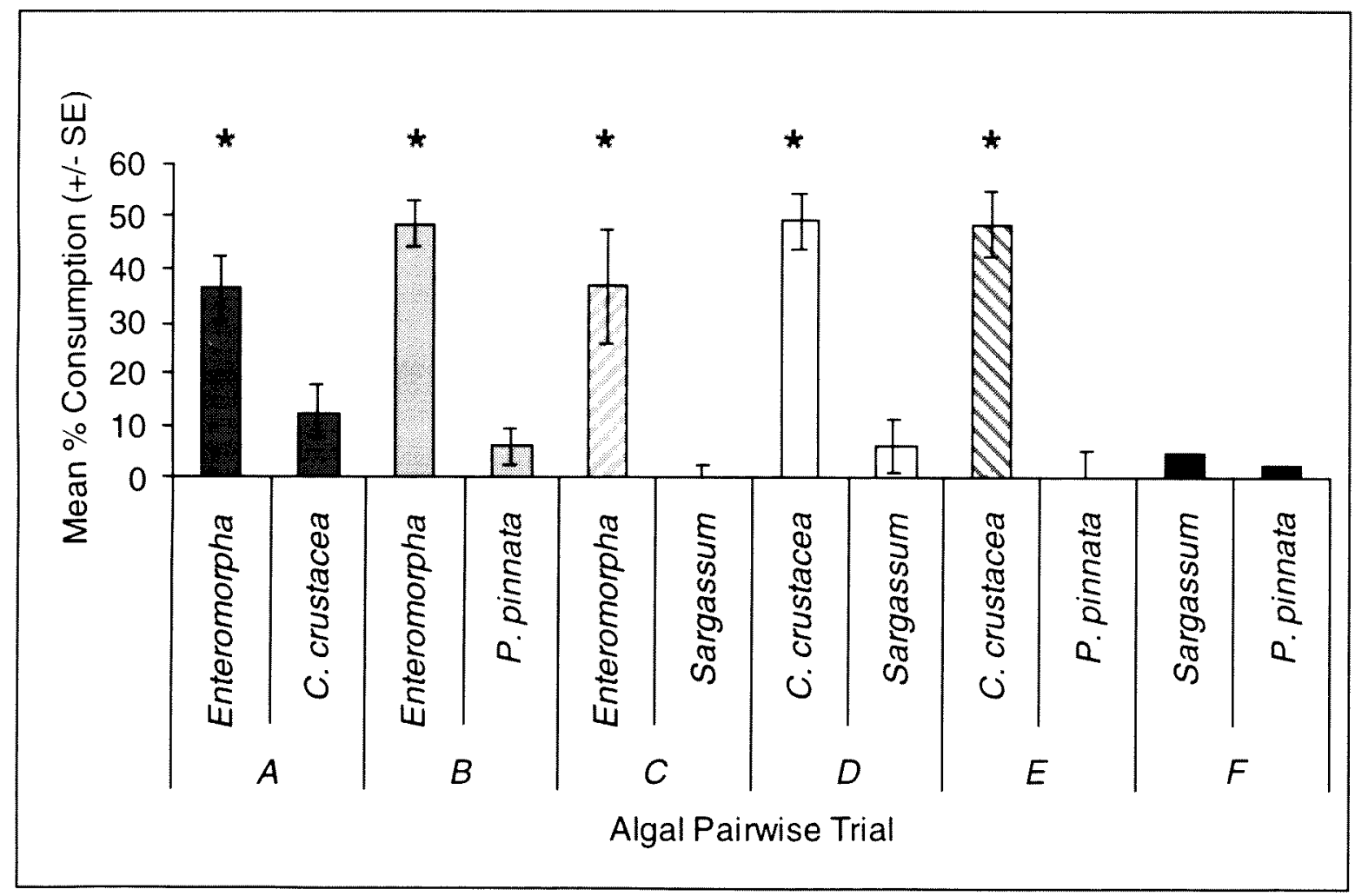

Figure 5 The mean percentage consumption $(+/-$ standard error) of each pairwise choice trial by Bursatella leachii. Asterisks $\left(^{*}\right)$ indicate significant choices as evidenced by the respective statistical test. Each colour code represents a single two-way choice experiment denoted by letters $\mathrm{A}-\mathrm{F}$ where $\mathrm{A}=$ Enteromorpha sp. vs. Calothrix crustacea, $\mathrm{B}=$ Enteromorpha sp. vs. Pterocladia pinnata, $\mathrm{C}=$ Enteromorpha sp. vs. Sargassum $\mathrm{sp} ., \mathrm{D}=$ Calothrix crustacea vs. Sargasstum sp., E = Calothrix crustacea vs. Pterocladia pimata and $\mathrm{F}=$ Sargassum sp. vs. Pterocladia pinnata. 
$\mathrm{p}=0.025$ ), Sargassum (Wilcoxon signed ranks test: $Z$ $=-2.100, \mathrm{p}=0.036$ ) and P. pinmata (Wilcoxon signed ranks test: $Z=-2.521, p=0.012$ ). Calothrix crustacea was consumed significantly more than Sargassum sp. (Wilcoxon signed ranks test: $Z=-2.521, p=$ 0.012 ) and P. pimnata (Wilcoxon signed ranks: -2.521 , $p=0.012$ ). There was no significant difference between the consumption of Sargassum sp. and $P$. pimata (Wilcoxon signed ranks test: $Z=-1.400$, $\mathrm{p}>0.05)$.

\section{Attractiveness}

The presence of individual sea hares on each alga yielded almost the same feeding preference hierarchy as that obtained by the direct measure of percentage consumption: Enteromorpha sp. $>$ C. crustacea $>$ P. pinnata and Sargassum sp. The place of $P$. pinnata and Sargassum sp. were reversed in this data set but there was no significant difference between the two. The mean number of times a sea hare was present on each alga during the pair-wise trial is shown in Figure 6. Bursatella leachii was recorded significantly more on Enteromorpha than C. crustacea (Wilcoxon signed ranks test: $Z=-2.058$, $\mathrm{p}=0.040$ ) or $P$. pinnata (Wilcoxon signed ranks: $Z=$ -2.251, $\mathrm{p}=0.024$ ). Bursatella leachii significantly preferred C. crustacea over $P$. pimata (Wilcoxon signed ranks: $Z=-2.041, p=0.041$ ). Each of the four algae presented to $B$. leachii had at least one individual found upon it at least once during the trials.

\section{DISCUSSION}

\section{Sea hare density}

The sea hare population at Shelly Beach reached extremely high densities during the sampling period compared to those previously reported (Carefoot 1987). In June 2003, another population irruption event was documented at the same location (Clarke 2004) where S. striatus reached high density $\left(3.84\right.$ per $\mathrm{m}^{2}$ ) while $B$. leachii was found at lower density $\left(0.24\right.$ per $\left.\mathrm{m}^{2}\right)$. Stylocheilus striatus has been reported in large numbers in association with blooms of Lyngbya majuscula in Hawaii (SwitzerDunlap and Hadfield 1979) and Guam (Paul and Pennings 1991; Nagle et al. 1998) but the densities were never quantified. Lowe and Turner (1976) reported substantially higher densities of $B$. leachii in Florida. However, the density reported for subtidal populations was based on the number of animals within a single aggregation. Other sea hare species have much lower densities than those recorded here. Carefoot (1987) reviewed the reported densities of several species of Aplysia and

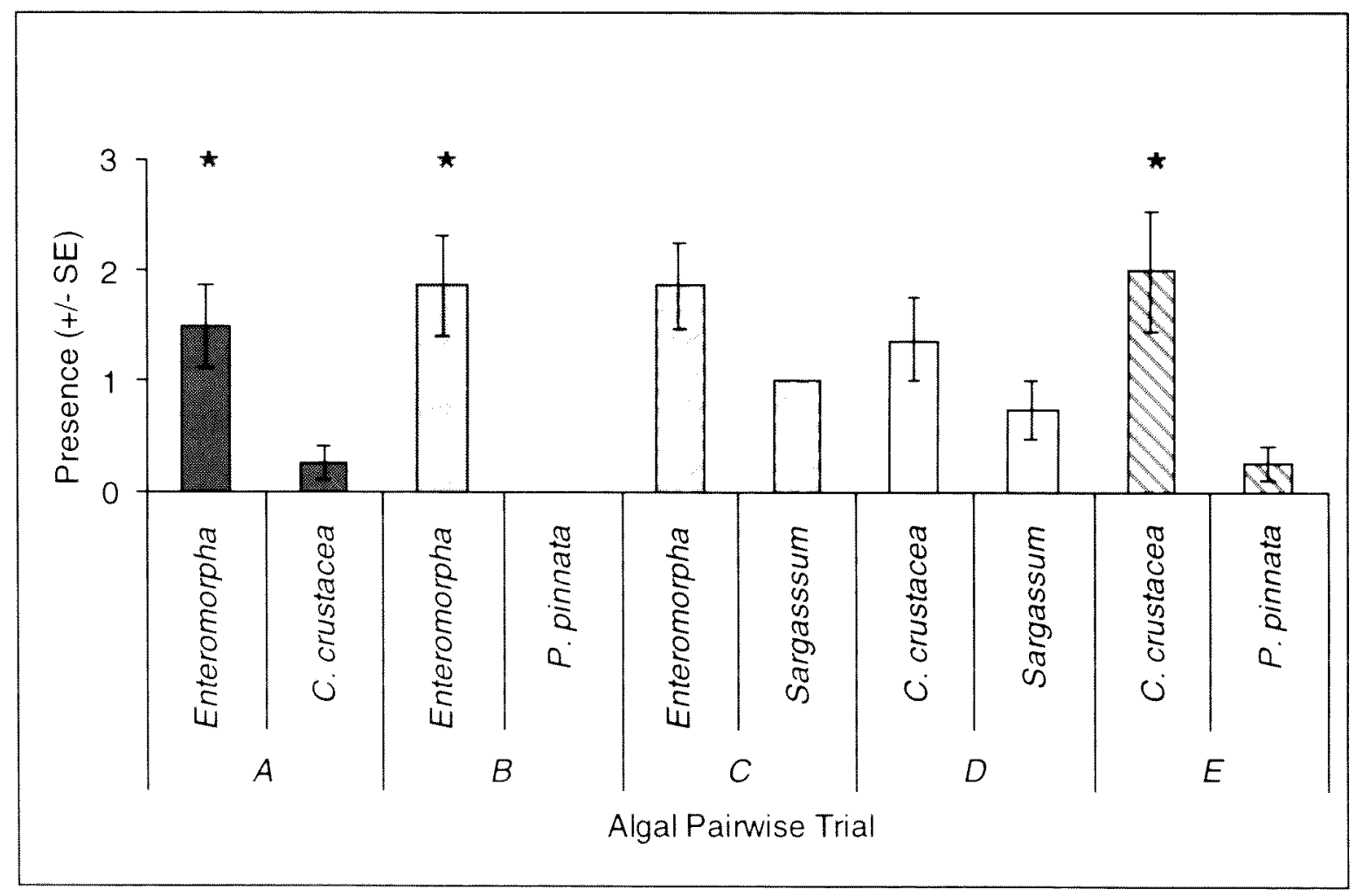

Figure 6 The mean number of times Bursatella leachii was recorded present on each alga within in each pairwise trial Asterisks (*) indicate statistically significant differences. Each colour code represents a single two-way choice experiment denoted by letters $\mathrm{A}-\mathrm{F}$ where $\mathrm{A}=$ Enteromorpha $\mathrm{sp}$. vs. Calothrix crustacea, $\mathrm{B}=$ Enteromorpha sp. vs. Pterocladia pinnata, $\mathrm{C}=$ Enteromorpla sp. vs. Sargassum sp., $\mathrm{D}=$ Calothrix crustacea vs. Sargassum sp., $\mathrm{E}=$ Calothrix crustacea vs. Pterocladia pimata and $\mathrm{F}=$ Sargassum sp. is. Pterocladia pimata. 
the average densities never exceeded 5.0 per $\mathrm{m}^{2}$ with most reports less than 1 per $\mathrm{m}^{2}$ (Willan 1979; Carefoot 1987). The low densities of Aplysia species have often been used as evidence for the limited role of all sea hare species in the marine community (Carefoot 1987; Rogers et al. 2003). However, the present study indicates much higher densities for $B$. leachii than the members of the more commonly studied genus Aplysia.

\section{Aggregation of sea hares on cyanobacterial blooms}

The co-occurrence of B. leachii and S. striatus and the bloom of the cyanobacterium, C. crustacea in 2002 has not been documented previously. At the same location in a subsequent year these sea hare species were associated with a different unidentified cyanobacteria species (Clarke 2004). Bursatella leachii is believed to have a more catholic diet than S. striatus (Wu 1980; Paige 1988). In Hong Kong, B. leachii consumes a range of macroalgae, preferring Enteromorpha prolifera, although cyanobacteria species were not tested (Wu 1980). In Florida, only species of cyanobacteria (including $L$. majuscula) were preferred in food choice tests and as metamorphic substrates (Paige 1988). In contrast, all previous reports have linked $S$. striatus with $L$. majuscula, its preferred food according to a number of authors (Paul and Pennings 1991; Pennings et al. 1996; Nagle et al. 1998)

During the present study, B. leachii preferred the green alga, Enteromorpha sp., to the cyanobacterium C. crustacea, the brown macroalga Sargassum sp., and the red macroalga $P$. pinnata. Enteromorpha sp. was preferred even to the cyanobacterial species ( $C$. crustacea) that the animals were seen to be feeding upon in the field. The occurrence of Enteromorpha sp. was extremely rare at the sampling site. Several sea hare species exhibit greater generalization of feeding preferences in the laboratory than are exhibited in the field (Saito and Nakamura 1961; Winkler and Dawson 1963; Carefoot 1987; Rogers et al. 2003). For example, some members of the genus Aplysia are often considered to specialize on red algae in the field (Carefoot 1987) and yet laboratory experiments have repeatedly shown their preference for green algae (Winkler and Dawson 1963; Rogers et al. 2003). Winkler and Dawson (1963) found that $A$. californica were only inhabiting red algae in the field, but preferred Enteromorpha in laboratory testing. Additionally, Saito and Nakamura (1961) found that $A$. juliana and $A$. kurodai consumed species of brown and red algae respectively in the field but both preferred species of Enteromorpha and Ulva in the laboratory.

The feeding preference hierarchy of B. leachii was identical whether obtained by testing palatability or attractiveness. Therefore the alga that individual sea hares chose to inhabit (the most attractive) was also the one that is the most consumed. Stylocheilus striatus has only been reported to feed upon $L$. majuscula overseas (Switzer-Dunlap and Hadfield 1977; Paul and Pennings 1991; Nagle et al. 1998). Though S. striatus and B. leachii seem to be common together, $B$. leachii is reported to feed on a number of red and green algae. The reason for the greater dietary range of $B$. leachii has not been previously discussed yet recent work on the way these two sea hares digest chemically rich foods has been conducted. Capper (2003) showed that there are differences in the way $B$. leachii and $S$. striatus deal with the secondary metabolites present in $L$. majuscula. B. leachii excretes secondary metabolites in the ink and faecal matter while $S$. striatus stores these metabolites in the digestive gland. The strategies of these two co-occurring species thus differ; $S$. striatus may have specialized to deal with the specific metabolites of $L$. majuscula while $B$. leachit excretes the chemicals and thus is more likely to be able to deal with a larger range of metabolites than S. striatus (Capper 2003).

Preferred choices may not offer the best long-term growth and fitness. Aplysia punctata consumes Enteromorpha sp. preferentially in the laboratory but animals on a diet of the red alga, Plocamitum sp., have lowered faecal production and better growth (Carefoot 1967). Monospecific diets of preferred chemically rich species have shown increased mortality for B. leachii and S. striatus (A. Capper, pers. comm.) and for A. paruula (Rogers et al. 1995). The next step in investigating the feeding preferences of $B$. leachii would be to compare the long term growth and reproduction of animals fed Enteromorpha sp. with those fed cyanobacteria.

\section{Population irruption dynamics}

The length-frequency distribution of this population can be used to investigate hypotheses about its dynamics (see Gev et al. 1984). It is important to note that length-frequency analysis is based on the assumption that length is a reasonable proxy for age. A single study found that length and age are directly related for $B$. leachii although only a small number of animals were used in experiments (Willan 1979). Other molluscs shrink under conditions of stress or low food availability (Russell-Hunter et al. 1984; Russell-Hunter 1985). This is unlikely in the present study because the concurrent cyanobacterial bloom provided an abundance of food, at least for the majority of the sea hare population irruption event. The hypothesis being tested was that sea hare population irruptions are the result of settlement of a single cohort on the cyanobacterial bloom. Similar studies with cooccurring Aplysia depilans and Aplysia fasciata in Israel showed a single recruitment pulse (Achituv and Susswein 1985). If a single pulse occurred we would expect that the length-frequency analysis 
would have detected a large cohort of animals of similar size moving through the size classes. This did not seem to be the case here, because for $B$. leachii, there was a continual addition of small recruits. In conjunction, there were also a small number of individuals in the large size classes. Thus, the size distribution of this population indicates that recruitment of individuals into the population is occurring throughout the duration of the cyanobacterial bloom.

Additionally, if the sea hare population irruption was a pulse-recruitment event we would expect to see a gradual increase in size and then an abrupt end to the population. The mean length of $B$. leachii was not significantly different through the duration of the cyanobacterial bloom. Thus, the animals were similar in size or size range throughout their presence in the seagrass beds. The presence of egg masses over the entire seven-week period also suggests that the population in Shelly Beach was not the result of a single recruitment pulse. Egg masses indicate the existence of reproductively mature and active adults within the population at all times. Aplysia species have been reported to restrict reproductive activities to certain habitats and certain seasons (Willan 1979; Carefoot 1987). For example, Willan (1979) found that the intertidal area he studied only contained immature Aplysia dactylomela and therefore no egg-laying occurred. The presence of sea hares from a wide size-range and the observed egg masses indicates that this population contained both immature and reproductively mature sea hares at the same time and therefore was not the result of a pulse recruitment event.

Large adults that were lost throughout the duration of the cyanobacterial bloom were either removed from the population by mortality, migration, or natural senescence. Decreasing abundance of cyanobacteria could cause starvationinduced mortality. Mortality could also be caused by predation. Nassarius sp. snails were observed feeding upon sea hare carcasses although it is unknown whether this predator caused the death of the animals or were merely scavenging. Other predators may move into the study area with high tide, which renders the area unavailable for study. A small number of predators have been shown to regularly prey upon sea hares and the species differ between systems. Known sea hare predators include the sea anemone Anthopleura xanthogrammica in California (Winkler and Tilton 1962), the pycnogonid Anoplodactylus evansi in temperate Australia (Rogers et al. 2000), the sea star Coscinasterias calamaria in New Zealand (Willan 1979) and the gastropods Navanax and Melo amphora (Pennings 1990a; Johnson and Willows 1999). It is unknown at this time whether natural predation events are an important source of mortality for the population dynamics of B. leachii and S. striatus in Shelly Beach.

The other possibility for the observed depletion of large sea hares is migration. If the animals were migrating to areas unavailable to observation then we would expect to see an abrupt appearance or disappearance of mature animals. The continual recruitment of small $B$. leachii into the population in 2002 rules out the possibility that this high-density occurrence was merely a roving population of adults. It would be expected that migration would cause an increase/decrease in abundance of all size classes, which was not observed here. There was a gradual decline of the number of large animals over time, suggesting that a mass migration was not the cause of the disappearance of sea hares in this population. This gradual decline is suggestive of a natural senescence of older sea hares, especially when it is considered that the timing of the population irruption event is comparable to the three month life span of B. leachii (Paige 1988).

The large amount of cyanobacteria biomass observed at Shelly Beach would provide a sizeable area for settlement. In Florida, B. leachii preferred to settle on three species of cyanobacteria, L. majuscula, Schizothrix calciola and Porphyrosiphon notarisii (Paige 1988). In Hawaii, L. majuscula is known to serve as a preferred site of settlement for S. striatus, along with a small number of red algae species (Switzer-Dunlap and Hadfield 1977). The physical conditions that promote cyanobacterial blooms may also be favourable for the influx of sea hare larvae into Shelly Beach seagrass beds. In addition, the ability of sea hare larvae to move towards chemical cues for settlement is currently unknown but if they possess a certain degree of swimming ability (as seen in reef fish larvae Fisher et al. 2000), these cyanobacterial blooms may send out strong signals into the water column for larvae to orient towards.

The consumption of epiphytic cyanobacteria by large numbers of sea hares may aid in maintaining the seagrass community composition. Sea hare grazing removed epiphytic cyanobacteria from seagrass blades. If seagrass blades become overgrown by epiphytes, sunlight is blocked and dieback may occur (Lubchenco and Gaines 1981). The sea hares did not completely consume the site's cyanobacteria biomass in this instance. However, the seagrass community likely derived some benefit from the short-lived sea hare irruption.

\section{CONCLUSIONS}

The sea hares B. leachii and S. striatus were found at densities far greater than those previously reported for other sea hare species. This suggests that these sea hare species may be important consumers of the sporadic cyanobacterial blooms that occur in sea grass beds and other coastal 
habitats. Analysis of the population dynamics revealed that the population irruption observed was not the result of a pulse recruitment event, but rather a continuous supply of recruits, in contrast to previous studies. Techniques such as population genetics and larval tows are needed to shed further light on recruitment patterns in this ecosystem.

The difference between the preferred alga in the laboratory and the prey species that $B$. leachii was feeding upon in the field reflects the complications associated with attempting to separate the various factors influencing feeding preferences in sea hares. It seems that the most important factors dictating feeding preferences in $B$. leachii are the palatability, abundance in the natural habitat, and though not directly tested here, likely the secondary chemistry of the food item. The demonstrated ability of $B$. leachii to reach large population sizes while feeding on a sub-optimal food source highlights the flexibility of feeding in these sea hares. The plasticity in feeding is likely to enhance the ability of sea hares to successfully exploit an abundant, but often, unpredictable resource. The aggregations of B. leachii observed at Shelly Beach, Townsville are not the result of single pulse recruitment. The evidence presented here suggests that the aggregations were supported by continual settlement in response to what may be a less than ideal food source.

\section{ACKNOWLEDGEMENTS}

This work was completed as part of the M.Sc. degree program at James Cook University. The author would like to thank Gilianne Brodie, Rocky de Nys and Annette Klussmann-Kolb for their supervision. Financial support was provided by CRC Reef, the Malacological Society of Australasia and James Cook University. Laboratory work was performed at the MARFU aquarium facilities at James Cook University. Two anonymous reviewers provided valuable advice on an earlier version of this manuscript.

\section{REFERENCES}

Achituv, Y. and Susswein, A. J. (1985). Habitat selection by two Mediterranean species of Aplysia: A. fasciata Poiret and $A$. depilans Gmelin (Mollusca: Opisthobranchia). Journal of Experimental Marine Biology and Ecology 85: 113-122.

Audeskirk, T. E. (1979). A field study of growth and reproduction in Aplysia californica. Biological Bulletin 157: 407-421.

Burla, H. and Ribi, G. (1998). Density variation of the zebra mussel Dreissena polymorpha in Lake Zurich, from 1976 to 1988. Aquatic Sciences 60(2): 145-156.

Capper, A. (2003). PhD Thesis. Ecotoxicology of the cyanobacterium, Lyngbya majuscula and five herbivores in Moreton Bay, Southeast Queensland, Australia. University of Queensland, Brisbane.
Carefoot, T. H. (1967). Growth and nutrition of Aplysia punctata feeding on a variety of marine algae. Journal of the Marine Biological Association of the United Kingdom 47: 565-589.

Carefoot, T. H. (1970). A comparison of absorption and utilization of food energy in two species of tropical Aplysia. Journal of Experimental Marine Biology and Ecology 5: 47-62.

Carefoot, T. H. (1987). Aplysia: its biology and ecology. Oceanography and Marine Biology Annulal Review 25: 167-284.

Clarke, C.L. 2004. The ecological role of sea hares (Opisthobranchia: Anaspidea) within tropical intertidal habitats. MSc Thesis. James Cook University, Townsville, Australia. 141 pp.

Coleman, N. (2001). 1001 Nudibranchs: Catalogue of IndoPacific Sea Slugs. Neville Coleman's Underwater Geographic Pty Ltd, Springwood, Qld.

Colgan, M. W. (1987). Coral reef recovery on Guam, Micronesia after catastrophic predation by Acanthaster planci. Ecology 68(6): 1592-1605.

Cote, I. and Reynolds, J. D. (1998). Tropical fish: Explosions and extinctions. Trends in Ecology and Evolution 13(12): 475-476.

Crawley, M. J. (1983). Herbivory: The Dynamics of AnimalMacrophyte Interactions. Blackwell Scientific Publications, Oxford.

Fisher, R., Bellwood, D. R. and Job, S. D. (2000). Development of swimming abilities in reef fish larvae. Marine Ecology Progress Series 202: 163-173.

Gev, S., Achituv, Y. and Susswein, A. J. (1984). Seasonal determinants of the life cycle in two species of Aplysia found in shallow waters along the Mediterranean coast of Israel. Journal of Experimental Marine Biology and Ecology 74: 67-83.

Ginsburg, D. W. and Paul, V. J. (2001). Chemical defenses in the sea hare Aplysia parvula: importance of diet and sequestration of algal secondary metabolites. Marine Ecology Progress Series 215: 261-274.

Hay, M. E., Pawlik, J. R., Duffy, J. E. and Fenical, W. (1989). Seaweed-herbivore-predator interactions: hostmacrophyte specialization reduces predation on small herbivores. Oecologia 81: 418-427.

Hayden, H.S., Blomster, J., Maggs, C. A. Silva, M.J. Stanhope, and Waaland, J. R. (2003). Linnaeus was right all along: Ulva and Enteromorpha are not distinct genera. European Journal of Phycology 38: 277-294.

Johnson, P. M. and Willows, A. O. D. (1999). Defense in sea hares (Gastropoda, Opisthobranchia, Anaspidea): Multiple layers of protection from egg to adult. Marine and Freshwater Behavioural Physiology 32: 147180.

Lanyon, J. M. and Marsh, H. (1995). Temporal changes in the abundance of some tropical intertidal seagrasses in North Queensland. Aquatic Botany 49: 217-237.

Lowe, E. F. and Turner, R. L. (1976). Aggregation and trailfollowing in juvenile Bursatella leachii plei (Gastropoda: Opisthobranchia). The Veliger 19(2): 153-155.

Lubchenco, J. and Gaines, S. D. (1981). A unified approach to marine macrophyte-herbivore interactions. I. Populations and communities. Annual Review of Ecology and Systematics 12: 405-437. 
Nagle, D. G., Camacho, F. T. and Paul, P. J. (1998). Dietary preferences of the opisthobranch mollusc Stylocheilus longicauda for secondary metabolites produced by the tropical cyanobacterium Lyngbya majuscula. Marine Biology 132: 267-273.

Nicotri, M. E. (1980). Factors involved in herbivore food preference. Journal of Experimental Marine Biology and Ecology 42: 13-26.

Paige, J. A. (1988). Biology, metamorphosis and postlarval development of Bursatella leachii Rang (Gastropoda: Opisthobranchia). Bulletin of Marine Science 42(1): 65-75.

Paul, V. J. and Pennings, S. C. (1991). Diet-derived chemical defenses in the sea hare Stylocheilus longicauda (Quoy et Gaimard 1824). Journal of Experimental Marine Biology and Ecology 151: 227-243.

Pawlik, J. R. (1989). Larvae of the sea hare Aplysia californica settle and metamorphose on an assortment of macroalgal species. Marine Ecology Progress Series 51: 195-199.

Pennings, S. C. (1990a). Predator-prey interactions in opisthobranch gastropods: effects of prey body size and habitat complexity. Marine Ecology Progress Series 62: 95-101.

Pennings, S. C. (1990b). Multiple factors promoting narrow host range in the sea hare, Aplysia californica. Oecologia 82: 192-200.

Pennings, S. C. (1991). Spatial and temporal variation in recruitment of Aplysia californica Cooper: patterns, mechanisms, and consequences. Journal of Experimental Marine Biology and Ecology 146: 253-274.

Pennings, S. C., Nadeau, M. T. and Paul, V. J. (1993). Selectivity and growth of the generalist herbivore Dolabella auricularia feeding upon complementary resources. Ecology 74(3): 879-890.

Pennings, S. C. and Paul, V. J. (1992). Effect of macrophyte toughness, calcification, and chemistry on herbivory by Dolabella auricularia. Ecology 73(5): 1606-1619.

Pennings, S. C., Weiss, A. M. and Paul, V. J. (1996). Secondary metabolites of the cyanobacterium Microcoleus lyngbyaceus and the sea hare Stylocheilus longicauda: palatability and toxicity. Marine Biology 126: 735-743.

Peterson, C. H. and Renaud, P. E. (1989). Analysis of feeding preference experiments. Oecologia 80: 82-86.

Plaut, I., Borut, A. and Spira, M. E. (1998). Seasonal cycle and population dynamics of the sea hare Aplysia oculifera in the northern Gulf of Eilat (Aqaba), Red Sea. Journal of Molluscan Studies 64: 239-247.

Rogers, C. N., De Nys, R. and Steinberg, P. D. (2000). Predation on juvenile Aplysia parvula and other small anaspidean, ascoglossan and nudibranch gastropods by pycnogonids. The Veliger 43(4): 330-337.

Rogers, C. N., De Nys, R. and Steinberg, P. D. (2002). Effects of algal diet on the performance and susceptibility to predation of the sea hare Aplysia parvula. Marine Ecology Progress Series 236: 2341-254.

Rogers, C. N., De Nys, R. and Steinberg, P. D. (2003). Ecology of the sea hare Aplysia paruula (Opisthobranchia) in New South Wales, Australia. Molluscan Research 23(3): 185-198.
Rogers, C. N., Steinberg, P. D. and De Nys, R. (1995). Factors associated with oligophagy in two species of sea hares (Mollusca: Anaspidea). Journal of Experimental Marine Biology and Ecology 192: 47-73. (1984).

Russell-Hunter, W.D. (1985). Physiological, ecological, and evolutionary aspects of molluscan tissue degrowth. American Malacological Bulletin 3(2): 213222.

Russell-Hunter, W.D., Browne, R. A. and Aldridge, D. W. (1984) Overwinter tissue degrowth in natural populations of freshwater pulmonate snails (Helisoma trivolvis and Lymnaea palustris). Ecology 65(1): 223-229.

Saito, Y. and Nakamura, N. (1961). Biology of the sea hare, Aplysia juliana, as a predator of the brown seaweed, Undaria pinnatifida - I. The feeding habit. Bulletin of the Japanese Society of Scientific Fisheries 27(5): 395.

Smith, R. L. (1996). Ecology and Field Biology. Harper Collins College Publishers, New York.

Switzer-Dunlap, M. and Hadfield, M. G. (1977). Observations of development, larval growth and metamorphosis of four species of Aplysiddae (Gastropoda: Opisthobranchia) in laboratory culture. Joumal of Experimental Marine Biology and Ecology 29: 245-261.

Switzer-Dunlap, M. and Hadfield, M. G. (1979). Reproductive patterns of Hawaiian aplysiid gastropods. In S. E. Stancyk (ed.), Reproductive Ecology of Marine Invertebrates 199-210. University of South Carolina Press, Columbia, South Carolina.

Walker, T. A. and O'Donnell, G. (1981). Observations on nitrate, phosphate, and silicate in Cleveland Bay, Northern Queensland. Australian Journal of Marine and Freshwater Research 32: 877-887.

Willan, R. C. (1979). The Ecology of Two New Zealand Opisthobranch Molluscs. Unpublished PhD Thesis. University of Auckland, Auckland, New Zealand. pp. 278 pp.

Williams, E. H., Jr., Bunckley-Williams, L., Lilyestrom, C. G., Larson, R. J., Engstrom, N. A., Ortiz-Corps, E. A. R., and Timber, J. H. (2001). A population explosion of the rare tropical/subtropical purple sea mane, Drymonema dalmatinum, around Puerto Rico in the summer and fall of 1999. Caribbean Journal of Science 37(1-2): 127-130.

Winkler, L. R. and Dawson, E. Y. (1963). Observations and experiments on the food habits of Californian sea hares of the genus Aplysia. Pacific Science 17: 102-105.

Winkler, L. R. and Tilton, B. E. (1962). Predation on the California sea hare, Aplysia californica Cooper, by the solitary great green sea anemone, Anthopleura xanthogrammica (Brandt) and the effect of sea hare toxin and acetylcholine on anemone muscle. Pacific Science 16: 286-290.

Wu, R. S. (1980). Foraging strategy in the sea hare Bursatella leachii (Mollusca: Opisthobranchia. Proceedings of the First International Marine Biological Workshop: The marine flora and fauna of Hong Kong and southern China, Hong Kong. Hong Kong University Press. 